\title{
PERBERDAYAAN ANAK JALANAN MELALUI PEMBUATAN KERAJINAN BERBAHAN KORAN BEKAS DI KECAMATAN PANAKKUAKNG KOTA MAKASSAR
}

\author{
Nurhidayatullah $\mathrm{D}^{*}$ \\ Abdul Wahid ${ }^{2}$ \\ Nur Afni ${ }^{3}$ \\ 1,2 STKIP Andi Matappa Pangkep, Pangkep, Indonesia \\ ${ }^{3}$ FKIP Universitas Islam Makassar, Indonesia \\ yayalibra1510@gmail.com ${ }^{1^{*}}$ \\ abdulwahidherlang@gmail.com ${ }^{2)}$ \\ nurafni.dty@uim-makassar.ac.id ${ }^{3)}$
}

\author{
Kata Kunci: \\ [Pemberdayaan Anak \\ Jalanan, Kerajinan \\ Berbahan Koran Bekas]
}

\begin{abstract}
Abstrak: Kertas koran berdasarkan jenisnya termasuk ke dalam limbah organik. Maka kertas koran yang sudah tidak terpakai dapat dikatagorikan sebagai sampah organik karena terbuat dari serat-serat alamiah yang dimanfaatkan untuk mencetak surat kabar koran. Kerajinan tangan berbahan dasar koran bekas sangat mungkin diberikan kepada anak jalanan di kecamatan panakkukang sebagai suatu inovasi baru dalam bidang ekonomi. Dengan mengambil manfaat dari limbah koran tersebut anak-anak dapat berkreasi dengan berbagai macam bentuk yang dinginkan. Dalam kegiatan pelatihan kerajinan tangan berbahan dasar koran ini kami menggunakan metode demontrasi dan praktek secara langsung. Hasilnya, karya yang terbuat dari koran bekas tersebut dapat dijual dan meningkatkan perekonomian mereka. Tujuan dari program ini adalah memberikan pelatihan mengenai cara membuat kerajinan tangan berbahan dasar koran bekas guna membantu mengatasi permasalahan ekonomi. Anak jalanan di kecamatan Panakkukang rata-rata berumur 6 sampai belasan tahun, anak-anak tersebut ada yang putus sekolah bahkan ada anak yang tidak pernah merasakan bangku sekolah sama sekali. Faktor yang menyebabkan hal tersebut yaitu kondisi ekonomi yang sulit sehingga tidak memungkinkan untuk mereka bisa bersekolah dengan layak. Berdasarkan kegiatan pembinaan keterampilan di Kecamatan Panakukkang Kota Makassar dalam mendaur ulang atau mengolah barang bekas minat anak jalanan menjadi lebih meningkat dari sebelumnya.
\end{abstract}

\section{Pendahuluan}

Undang-Undang Dasar 1945 Pasal 27 Ayat 2 menyatakan bahwa" fakir miskin dan anak terlantar dipelihara oleh Negara". Artinya pemerintah mempunyai tanggung jawab terhadap pemeliharaan dan pembinaan anak-anak terlantar, termasuk anak jalanan. Hakhak asasi anak terlantar dan anak jalanan, pada hakekatnya sama dengan hak-hak asasi manusia pada umumnya, seperti tercantum dalam UU No.39 Tahun 1999 tentang Hak 
Asasi Manusia, dan Keputusan Presiden RI No. 36 Tahun 1990 tentang pengesahan Convention on The Right of the Child (Konvensi tentang hak-hak Anak).

Menurut Hurlock (2012), aspirasi didefinisikan sebagai keinginan yang kuat dan usaha yang dilakukan untuk meraih sesuatu yang lebih tinggi dari keadaan sekarang. Keinginan tersebut dapat berupa keinginan meningkatkan status individu, maupun keinginan yang tidak wajar dan terlalu berani.

Anak merupakan masa depan bangsa yang wajib dilindungi dan dipenuhi kebutuhan hidupnya. Apalagi Hidup di jalanan menimbulkan berbagai permasalahan yang sangat rentan dihadapi oleh anak jalanan. Anak jalanan yang belum stabil pada usianya, mudah sekali dipengaruhi oleh orang yang lebih dewasa. Anak-anak yang bekerja untuk keluarga maupun untuk kebutuhan dirinya sendiri penuh dengan risiko.

Pengembangan ekonomi lokal perlu dilakukan untuk mendukung perkembangan sektor-sektor ekonomi yang mempunyai potensi menciptakan kesempatan kerja yang luas dan memiliki prospek yang baik dalam meningkatkan kesejahteraan masyarakat di suatu wilayah. Maka dari itu dengan adanya program ekonomi kreatif yang dilakukan, diharapkan mampu merubah sedikit demi sedikit perekonomian anak jalanan dengan mengadakan inovasi baru untuk menjadikan anak jalanan memiliki mata pencaharian yang lebih beragam dengan memanfaatkan barang bekas yang nantinya dapat bernliai seni dan bernilai jual atau bernilai ekonomis.

Pemanfaatan sumber daya yang bukan hanya terbarukan bahkan tidak terbatas yaitu ide, gagasan, bakat atau talenta dan kreativitas. Nilai ekonomi dari suatu produk atau jasa di era kreatif tidak lagi ditentukan oleh bahan baku atau sistem produksi seperti pada era industri, tetapi lebih kepada pemanfaatan kreativitas dan penciptaan inovasi melalui pengembangan teknonogi yang semakin maju. Industri tidak dapat lagi bersaing di pasar global dengan hanya mengandalkan harga atau kualitas saja, tetapi harus bersaing berbasiskan inovasi, kreativitas dan imajinasi. Dalam kegiatan mengatasi masalah ekonomi dan perilaku menyimpang untuk anak-anak jalanan di kecamatan panakkukang, maka dimanfaatkanlah salah satu jenis limbah sampah yaitu sampah organik seperti kertas koran.

Permasalahan menurut Suryadi \& Yeni Miftahul Zanah (2019) yang terjadi pada anak jalanan korban eksploitasi ekonomi antara lain, Pendidikan, pada umunya anak jalanan korban eksploitasi ekonomi mengalami putus sekolah atau tidak sekolah disebabkan oleh sebagian waktunya dihabiskan di jalan untuk mencari uang.

Selain faktor ekonomi, banyak penyebab yang saling mempengaruhi turunnya anak ke jalan, seperti: kemiskinan, penganguran, perceraian dan kekerasan dalam rumah tangga (Aribowo, 2009). Jika tidak segera diatasi maka kondisi anak jalanan itu semakin gawat, dan masa depan mereka menjadi suram. Hal ini memungkinkan setelah dewasa mereka akan menjadi warga masyarakat yang menyusahkan orang lain. Padahal setiap masalah yang menyentuh kehidupan anak dalam jumlah yang besar akan berdampak tidak menguntungkan bagi kehidupan bangsa secara keseluruhan di masa mendatang.

Anak jalanan di kecamatan Panakkukang rata-rata berumur 6 sampai belasan tahun, anak-anak tersebut ada yang putus sekolah bahkan ada anak yang tidak pernah merasakan bangku sekolah sama sekali. Faktor yang menyebabkan hal tersebut yaitu 
kondisi ekonomi yang sulit sehingga tidak memungkinkan untuk mereka bisa bersekolah dengan layak.

Akibat dari tidak mendapatkan pendidikan di sekolah anak-anak tersebut tidak memiliki pengetahuan dan keterampilan dalam pemanfaatan koran bekas, dan rata-rata anak jalanan tersebut sangat membutuhkan mengenai edukasi pencegahan perilaku menyimpang.

Kertas koran berdasarkan jenisnya termasuk ke dalam limbah organik. Maka kertas koran yang sudah tidak terpakai dapat dikatagorikan sampah organik karena terbuat dari serat-serta alamiah yang dimanfaatkan untuk mencetak surat kabar koran. Kerajinan tangan berbahan dasar koran bekas sangat mungkin diberikan kepada anak jalanan di kecamatan panakkukang sebagai suatu inovasi baru dalam bidang ekonomi. Dengan mengambil manfaat dari limbah koran tersebut anak-anak dapat berkreasi dengan berbagai macam bentuk yang dinginkan. Dalam kegiatan pelatihan kerajinan tangan berbahan dasar koran ini kami menggunakan metode demontrasi dan praktek secara langsung. Hasilnya, karya yang terbuat dari Koran bekas tersebut dapat dijual dan meningkatkan perekonomian mereka.

Berdasarkan analisis situasi yang di jelaskan diatas kecamatan panakukkang memiliki berbagi macam masalah dalam pemanfaaatan barang bekas dan sampah plastik yang terdapat dilingkungan sekitarnya diantaranya sebagai berikut: (1) Kurangnya minat dalam mengolah barang bekas/palstik; dan (2) Kurangnya keterampilan dalam mengolah barang bekas / plastik.

\section{Rumusan Masalah}

Berdasarkan latar belakang diatas, maka masalah yang difokuskan adalah bagaimana cara mengolah koran bekas sebagai bahan dasar kerajinan tangan di anak jalanan?

\section{Tujuan Program}

Tujuan dari program ini adalah memberikan pelatihan mengenai cara membuat kerajinan tangan berbahan dasar koran bekas guna membantu mengatasi permasalahan ekonomi.

\section{Manfaat Kegiatan}

Program ini nantinya diharapkan dapat mengatasi masalah perekonomian anak jalanan di kecamatan Panakkukang Kota Makassar.

\section{Metode Pelaksanaan}

Metode adalah instrumen yang digunakan peneliti untuk mengumpulkan data. Metode menyangkut masalah cara kerja: yaitu cara untuk memahami fokus kajian yang menjadi sasaran dari ilmu yang bersangkutan. Metode adalah suatu cara kerja atau mekanisme tindakan menurut kaidah tertentu dalam konteks ilmu pengetahuan tertentu. Metodologi menerjemahkan suatu paradigma dalam bahasa penelitian, dan menunjukkan bagaimana keberadaan dunia nyata dapat dijelaskan, ditangani, dipelajari.16 Untuk analisa lebih lanjut tentang peranan dalam upaya pemberdayaan anak jalanan, penelitian 
ini menggunakan jenis penelitian lapangan yang bersifat kualitatif, lokasi. Penelitian ini menggunakan pendekatan kualitatif.

Pendekatan kualitatif ialah berusaha untuk mempelajari masyarakat secara ilmiah yang fokus pada kehidupan kelompok masyarakat dan hasil interaksi sosial dari kelompok itu. Pemahaman ini akan digunakan sebagai alat analisa untuk melihat fenomena peran lembaga dalam suatu masyarakat. Demikian pula dalam penelitian yang akan dipakai, penulis menggunakan beberapa metode yang dijadikan sebagai alat untuk sasaran yang hendak dikaji.

Permasalahan utama yaitu kondisi ekonomi yang buruk serta orang tua mereka berstatus pengangguran, serta minimnya keahlian khusus yang mereka kuasai membuat mereka tidak berinisiatif untuk mencari pekerjaan yang lebih menguntungkan, sehingga bergantung kepada hasil minta-minta di jalanan.

Tabel 1. Kondisi Sebelum dan Sesudah Program Harapan

\begin{tabular}{ll}
\hline \multicolumn{1}{c}{ Kondisi sebelum program } & \multicolumn{2}{c}{ Harapan sesudah program } \\
\hline $\begin{array}{l}\text { Anak jalanan tersebut tidak mengetahui } \\
\text { pembuatan kerajinan tangan berbahan } \\
\text { dasar koran bekas. }\end{array}$ & $\begin{array}{l}\text { Anak jalanan tersebut mengetahui } \\
\text { pembuatan kerajinan tangan berbahan } \\
\text { dasar koran bekas }\end{array}$ \\
\hline
\end{tabular}

Metode pengembangan yang akan dilaksanakan merupakan sebuah rangkaian tahapan yang disusun secara sistematis, berikut adalah gambaran flow map yang akan berjalan:

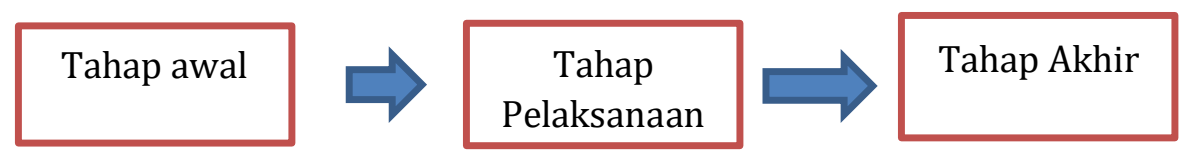

Kegiatan ini dibagi menjadi 3 tahapan yaitu tahap awal (persiapan), tahap pelaksanaaan, dan tahap akhir yang kesemuanya itu dilaksanakan kurang labih selama 2 bulan. Adapun tahapan kegiatan yang dilaksanakan adalah sebagai berikut:

\section{a. Tahap Awal (Persiapan)}

Pada tahap ini, tim pelaksana mengumpulkan alat-alat maupun bahan yang dipakai selama tahapan pelaksanaan kegiatan.

\section{b. Tahap Pelaksanaan}

- Pelatihan

Tahap pelatihan dilakukan dengan menggunakan metode demontrasi dan praktek secara langsung dengan memperhatikan kondisi anak jalanan tersebut.

- Edukasi Pada

Tahap ini edukasi akan dilakukan melalui pendekatan kepada anak-anak tersebut lalu memberikan edukasi mengenai perilaku menyimpang, agar anakanak tersebut memiliki pengetahuan mengenai perilaku menyimpang dan dapat menghindarinya.

- Evaluasi

Tahap evaluasi dilakukan dengan melihat tingkat keberhasilan kegiatan.

Evaluasi dilaksanakan selama proses kegiatan dan pada akhir kegiatan. 


\section{c. Tahap Akhir}

Hal terakhir yang dilakukan adalah menganalisis pencapaian tujuan yang hendak dicapai serta menyusun laporan akhir kegiatan

\section{Mekanisme dan Desain Kegiatan}

Kegiatan pembinaan ini dilaksanakan di Kecamatan Panakukkang Kota Makassar yang dilaksanakan selama 2 bulan, adapun kegiatan-kegiatan yang dilaksanakan didalam pembinaan sebagai berikut:

1. Memberikan pembelajaran pembuatan kerajinan tangan dari koran bekas

2. Memberikan keterampilan dalam mendaur ulang/mengolah barang bekas (koran) menjadi barang yang bermanfaat, misalnya koran bekas dijadikan pajangan dinding, tempat pensil, kotak tissu dan kursi mini

\section{Hasil dan Pembahasan}

Berdasarkan hasil temuan peneliti dapat diperoleh dari suatu informasi mengenai pembedaayaan anak jalanan dalam keterampilannya mengolah bahan tak habis pakai dalam hal ini koran, melalui tahapan yaitu tahapan penyadaran, tahap trasformasi pengetahuan, tahap peningkatan intelektualitas.

Pembuatan kerajinan bahan bekas yang membuat anak-anak dapat mengembangkan kemampuan yang mereka miliki, bakat dan minat dapat tersalurkan serta dapat menciptakan jiwa kreatif dan mandiri untuk anak asuh. Karena keterampilan merupakan kemampuan beradaptasi dan berilaku positif yang memungkinkan seseorang mampu menghadapi berbagai tuntunan dan tantangan dalam kehidupan sehari-hari secara efektif.

Dari data-data yang kami analisis maka kami dapat menyimpulkan dalam bentuk tabel frekunsi (Lihat Tabel 2) dari berbagai faktor pendukung dan penghambat, sehingga pelaksanaan pengabdian ini dapat berjalan dengan lancar, maka terlihat dari segi seberapa manfaat ka pengetahuan mereka tentang pembuatan kerajinan dari bahan bekas itu sendiri.

Tabel 2. Hasil Distribusi frekuensi variabel dalam mengolah daur ulang barang bekas menjadi barang bermanfaat.

\begin{tabular}{cccc}
\hline Interval Nilai & Frekuensi & Persen & Kategori \\
\hline $141-150$ & 2 & 9,52 & Sangat rendah \\
$151-160$ & 4 & 16,67 & Rendah \\
$161-170$ & 8 & 23,81 & Sedang \\
$171-180$ & 10 & 28,57 & Tinggi \\
$181-190$ & 7 & 21,43 & Sangat tinggi
\end{tabular}




\begin{tabular}{ccc}
\hline Jumlah & 30 & 100 \\
\hline
\end{tabular}

Sumber: Survei tahun 2019

Pada Tabel 2 terlihat bahwa Pada tabel di atas, menunjukkan bahwa terdapat 4 atau 9,52 persen responden yang dalam mengola daur ulang barang bekas menjadi barang bermanfaat sangat rendah, selanjutnya 7 atau 16,67 persen responden yang tergolong kategori rendah tingkat kecerdasan dalam mengola daur ulang barang bekas menjadi barang bermanfaat, kemudian 10 atau 23,81 persen responden kecerdasan emosionalnya dalam mengola daur ulang barang bekas menjadi barang bermanfaat tergolong kategori sedang, dan 12 atau 28,57 persen responden dalam mengola daur ulang barang bekas menjadi barang bermanfaat tergolong kategori tinggi, serta ada 9 atau 21,43 persen responden dalam mengola daur ulang barang bekas menjadi barang bermanfaat sangat tinggi

\section{Kesimpulan}

Berdasarkan pelaksanaan kegiatan yang telah dilakukan, beberapa hal yang dapat disimpulkan antara lain:

a. Berdasarkan kegiatan pembinaan keterampilan di Kecamatan Panakukkang Makassar dalam mendaur ulang atau mengolah barang bekas minat anak jalanan menjadi lebih meningkat dari sebelumnya.

b. Keterampilan dalam mengolah barang bekas menjadi lebih baik setelah diadakan pembinaan mendaur ulang barang bekas di Kecamatan Panukkang.

\section{Ucapan Terimakasih}

Terima Kasih kepada STKIP Andi Matappa Pangkep yang telah memberikan dana dan kesempatan kepada kami untuk melakukan Tri Darma Perguruan Tinggi sebagai dosen.

\section{Referensi}

Ardianto, Ervinaro. 2011. Metodologi Penelitian untuk Public Relations Kuantitatif dan Kualitatif. Bandung: Remaja Rosdakarya

Cutlip, Scott M, Center dan Broom. 2006. Effective Public Relations. Jakarta: Kencana Prenada Media Group.

Hadi, Nor. 2011. Corporate Social Responsibility. Yogyakarta: Graha Ilmu. Iriantara, Yosal. 2013. Public Relations. Jakarta: Erlangga Jefkins

Ibnu Aribowo. 2009. Upaya Pemberdayaan Anak Jalanan Melalui Rumah Singgah Diponegoro Yogyakarta". Jurnal DIMENSIA', Volume 3, No. 1, Maret

Frank. dan Daniel Yadin. 2003. Public Relations Edisi Kelima. Jakarta: Erlangga.

Katz, Bernard. 1994. Komunikasi Bisnis Praktis. Penerjemah: Soeharsono. Pustaka: Benaman Presindo 
Mardikanto, Totok. 2018. Corporate Soial Responsibility (Tanggung Jawab Sosial Perusahaan). Bandung: Alfabeta

Rumanti, Maria Assumpta. 2012. Dasardasar Public Relations (Teori dan Praktik). Jakarta: PT Gramedia Widiasarana Indonesia.

Suryadi \& Yeni Miftahul Zanah. 2019. "Pemberdayaan Anak Jalanan Berbasis Komunitas”. Jurnal ibda. 